\title{
Studies of the National Subjectivity of Chinese Films: History, Status quo and Multi-dimensional Construction
}

\author{
Zhang Xianxi \\ School of Communication, Zaozhuang University \\ No.1 Bei'an Road, Shizhong District, Zaozhuang, China \\ Email: hhxzxx1977@163.com
}

\begin{abstract}
Starting from the studies of nationalization of Chinese films, the studies of the national subjectivity of Chinese films have become the hotspot and frontier of the current academic research in China since the success of the International Symposium of Chinese Films and National Subjectivity in 2007. Based on the history and status quo of national subjectivity research, this paper puts forward the strategies of constructing the subjectivity of Chinese films from the perspectives of inheriting the Chinese cultural genes, promoting Chinese style and highlighting Chinese spirits.
\end{abstract}

Keywords-Chinese Film School; Subjectivity; Cultural genes; The Chinese styles; The Chinese spirits

\section{INTRODUCTION}

After over 100 years' development, Chinese films have ranked high in the world in terms of not only quantity but also quality. However, the lack of distinct national subjectivity doesn't match China's position as the second biggest film market in the world. Therefore, it's of great necessity to carry out studies of national subjectivity of Chinese films, which, to be specific, includes the search for the distinct characteristics and profound connotations, the confirmation of the most appropriate reference of Chinese films differing from those of other countries, the building of national confidence of Chinese films and the promotion of Chinese film creation. The significance of carrying out the national subjectivity studies lies in the exploration of Chinese film forms different from the ideologies and styles of film creation in other countries, and of the identification of the features of Chinese films, so as to highlight the Chinese styles with the efforts of Chinese directors, promote the dissemination, home and abroad, of Chinese films and enhance their overseas influence. Hence, studies of national subjectivity of Chinese films have become the research hotspot and frontier of the current Chinese academic circle

\section{History OF THE STUDIES OF NATIONAL SUBJECTIVITY OF CHINESE FILMS}

The current studies of national subjectivity in China focus on the Chinese philosophy and the subjectivity of Chinese culture. In contrast, the national subjectivity studies of Chinese films, although having become the research hotspot and frontier, have made comparatively few representative achievements. Historically, the national subjectivity studies of Chinese films can be traced back to the studies of nationalization of Chinese films which began from the early 1960s when there was a relatively loose context for artistic creation. In the paper To Look for Treasures in the Chinese Tradition: Learning Notes on the National Forms of Films (Motion Picture Arts, 1962) Director Xu Changlin put forward how to inherit the Chinese tradition of literature and art, which offered a new thinking on Chinese films. This paper was serialized thereafter, having exerted some influences on the then Chinese film circle. In the early 1980s, the studies of nationalization of Chinese films were further expanded to the field of the modernity of Chinese films and thereby launched an academic debate centered on the nationalization of films, the focus of which lies in whether Chinese films bears national characteristics, whether Chinese films should accord with the Chinese people's habits and customs, cultural traditions and psychological state, etc. The debate lasted for quite few years but ended up fruitless due to the mere theoretical discussions but with no action.

It's 30 years later, that is, until 2013, that the nationalization of Chinese films was mentioned again. That year, the success of the International Symposium of Chinese Films and National Subjectivity held by Beijing Normal University put the topic of the nationalization of Chinese films on the agendas of the Chinese film circle again. At the Symposium, Pro. Huang Huilin of Beijing Normal University put forward the concept and theory assumption of the Thirdpole film culture and summed up its characteristics, i.e. nationality, cosmopolitanism and modernity [1].

Jia Leilei, vice-president of Chinese National Academy of Arts, argued that, based on the Confucian view of benevolence, Chinese films should demonstrate the outlook on cultural values which is universal to all human beings [2]. 
Pro. Huang Shixina from Beijing Film Academy made an analysis of the national subjectivity of Chinese films at the level of genre, holding that the Chinese youth movies, expressing "the true, the good and the beautiful" with the core of Chinese elements, played an important role in carrying forward the national culture, and that they not only have attracted the Chinese audience and made good box office but also would be expected and loved by more audiences in the world [3].

The follow-up studies after this symposium failed to make any expected achievements and eventually fell into oblivion.

\section{Status QUO OF THE STUdiEs OF NATIONAL SUBJECTIVITY OF CHINESE FILMS}

It is in 2016 that the national subjectivity studies of Chinese films were led to an in-depth study. That year Hou Guangming published in China Art a seminal paper Significance and Route of Construction of the Chinese Film School putting forward formally the concept of "Chinese Film School".[4]

Since 2017 influential domestic film scholars began to shift their focus to relevant studies of Chinese Film School, which gave rise to the booming of the national subjectivity studies of Chinese films. Quite many achievements sprang up. Two papers, written by Zhou Xing, are representative, that is, Construction of Chinese Film School: Concept and its Adaptability from the Perspective of Communications, which explores the concept and its adaptability of Chinese Film School from the perspective of communications, and Chinese Film School: Thoughts on Diversity Construction, which examines the characteristics in diversity of Chinese Film School from the perspective of construction. All these show that great progress has been made in the national subjectivity studies of Chinese films. Wang Haizhou and Li Daoxin in their respective papers The Historical Context and Cultural Core of Chinese Film School and Zheng Zhengqiu and the Emergence of Chinese Film School make a diachronic study of the development of Chinese films and explore the practicality of using Chinese Film School to identify the national subjectivity of Chinese films, which further the national subjectivity studies in breadth and depth. While great achievements have been made since 2017, there still remains much space for further exploration. The current studies are only the tip of the iceberg, so to speak. The national subjectivity studies urgently need to be deepened.

The studies of national subjectivity of Chinese films, a systematic subject, involve not only the ontological studies of films but also interdisciplinary studies. Researchers not only need a global vision to explore the history, status quo, schools, features and theories of films around the world, but also carry out ontological studies of Chinese films with focus on history, status quo, intergeneration, aesthetics and so forth. In general, the studies of national subjectivity can be conducted at three levels: macro-level studies of the history and culture of Chinese films, middle-level studies of Chinese film traditions like martial arts, ethics, emotional narration, oriental image aesthetics, etc., and micro-level studies of the influential film creation and representative figures of different periods [5].
These three-level studies define the diversity of the studies of national subjectivity of Chinese films.

\section{Multi-dimensional CONSTRUCTION OF NATIONAL SUBJECTIVITY OF CHINESE FILMS}

The diversity of national subjectivity of Chinese films makes it hard to find a unified description to generalize the characteristics of Chinese films. Only by being deeply rooted in the Chinese culture and aesthetics and in the Chinese directors' practice to explore Chinese films with unique styles and features, which differ from the Western films featuring extreme pursuit of arts and profits, Indian films featuring song and dance and Japanese films featuring expressions of dual character, can Chinese Film School with Chinese characteristics be constructed. The establishment of Chinese Film School requires the exploration of the unique Chinese cultural genes and national ideology embodied in Chinese films, employment of image codes and ways of expressions fit for Chinese stories, and infusion of Chinese styles, spirits and socialist core values. With a thorough examination of the history and status quo, forms and connotations of Chinese films, the national subjectivity of Chinese films can be generalized as Chinese genes, styles and spirits.

The Chinese cultural genes, the basic units for the dissemination or imitation of Chinese culture, and also the smallest message units and links bearing the genetic codes of the Chinese cultural system, are essential for the national subjectivity of Chinese films. The Chinese cultural gene can find its expressions in myths, legends, hardship consciousness and rebellious spirits embodied in them, symbols and totems (dragon, phoenix, etc.), religion, literature, arts, architecture, apparel and accessories, traditional Chinese medicine, food, Confucianism and Taoism, ceramics, etc. These cultural genes serve as inexhaustible sources for Chinese film creation and become important features and clear-cut symbols making Chinese films distinct from those of other countries. The Chinese cultural genes mainly include the following ones: first, myth genes in films adapted from stories of Chinese myths, such as Legend of the Demigods, Legend of Eight Immortals, Myth, Green Snake, Lotus Lantern, The Girl in the Picture, The Story of the Stone, Fairy Couple, Legend of Ji Gong, Painted Skin, etc. These films reflect not only hardship consciousness of Chinese culture but also ancient people's rebellious spirits; second, genes of Confucianism and Taoism passed from the birth of Chinese films till today, which can be found in quite many films, ranging from China's first-generation directors' (Zhang Shichuan's and Zheng Zhengqiu's) films like Die for Marriage, Victims of Opium, Orphan Rescues Grandpa, etc. to Springtime in a Small Town, Spring River Flows East and Legend of Tianyun Mountain, to China's fifth-generation directors' films like King of the Children, Loess land, Red Sorghum, Raise the Red Lantern, Ju Dou, The Story of Qiu Ju, Peacock, etc.; third, genes of traditional Chinese medicine which can be found mainly in the films telling stories about traditional Chinese medicine, such as Hua Tuo and Cao Chao, Li Shizhen, Treatment: the Guasha, Crazed Passion Medico Ye Tianshi, The Master of Chinese Medicine, Our Tradition, Tenday Talk of Widow, etc. The Chinese films that contain rich Chinese cultural genes are not confined to those mentioned 
above. Chinese films are originated from the Chinese culture, which determines they are branded much or less with Chinese cultural genes and thus bear the characteristics of national subjectivity. Therefore, the Chinese cultural genes become an important dimension to identify the nationality of Chinese films.

The Chinese style is viewed as the best identification of the national subjectivity of Chinese films. Currently, the total number of screens in China is up to 55,000 ranking top in the world. However, the Hollywood movies take up a larger proportion, which is not in accordance with our position as a great cultural country. The construction of national subjectivity requires not only more market share but also the promotion of domestic film creation, and unceasing efforts to develop better Chinese-style films featuring the era and national spirits. The creation of Chinese-style films entails confidence in Chinese culture, respect of Chinese history and cultural tradition, and creative transference and innovation of concepts, spirits and wisdom peculiar to Chinese people. In the history of Chinese films, there is no lack of Chinese-style films. For example, Song of the Fishermen, Goddess, Spring River Flows East and Springtime in a Small Town in the early periods and Loess land, Red Sorghum and Farewell My Concubine in the 1980s and 90s are all typical Chinese-style films. Even those films that were put on in recent years with good performance in box office and public popularity, such as Wolf Warriors 2, Operation Red Sea and Dying to Survive and so on, can also rank in the list. Therefore, the Chinese style is viewed as an important dimension to make Chinese films distinct from those of other countries.

The Chinese spirits can be seen as the soul of national subjectivity of Chinese films. The Chinese spirits (national spirits), the bond for the cohesiveness of national emotion of the Chinese people in the 5000-year development of the Chinese nation, and the source of tenacious vitality in Chinese nation's unceasing striving, include the family-country emotion embodied in the left-wing works like Spring River Flows East, Eight Thousand Li of Cloud and Moon, Crow and Sparrow, etc., entrepreneurship in Bridge and Red Flag Chronicle, patriotism in Woman Basketball Player No.5,etc., and consistently accompany the development and improvement of Chinese films. And there are also other films like Life, The River without Buoys, Old Well, In the Wild Mountains and Black Canon Incident showing the Chinese spirits. The films like Legend of Tianyun Mountain, The Herdsman, Hibiscus Town, My Memories of Old Beijing and Evening Rain triggered the reflections of China. One and Eight, Loess Land, Red Sorghum and the like initiated the new style. These films of great vitality reflect the great changes in Chinese society, open new tradition of Chinese films and prop up the Chinese spirits embodied in the Chinese films, and eventually make the Chinese spirits an important reference to the national subjectivity of Chinese films.

The Chinese cultural genes, the Chinese style and the Chinese spirits, the three dimensions that constitute the national subjectivity of Chinese films, are interwoven with each other, inseparable. Ever since the earliest Chinese film Dingjun Mountain first incorporated Chinese cultural genes into its creation, Chinese films have become the important carrier inheriting Chinese cultural genes and demonstrating Chinese styles. Only by incorporating and exploring fully Chinese cultural genes, and showing consciously the Chinese spirit of sharing a common fate with people, heart to heart, can more high-quality films be created with Chinese styles.

\section{CONCLUSION}

A diachronic study of the history and status quo of the development of Chinese film shows that the national subjectivity of Chinese films has always been an important topic in the development and foreign communication of Chinese films. Although the studies in this respect have made some achievements, there remain quite many issues for further exploration. Based on the traditional Chinese culture and the Chinese film history and in the context of the current development of Chinese films, it's a feasible way to construct the national subjectivity of Chinese films from the three dimensions: inheritance of the Chinese cultural genes, formation of Chinese film styles and exploration of Chinese film spirits, which deserves thinking in Chinese directors' creation of films. The solutions of these issues will contribute to the highlighting of Chinese characteristics and overseas dissemination of Chinese films.

\section{REFERENCES}

[1] Wang Fei. Summary of the International Symposium of Screen World \& Chinese Dreams: Chinese Films and National Subjectivity[J]. Hundred Schools in Arts, 2013(8):80.

[2] Wang Fei. Summary of the International Symposium of Screen World \& Chinese Dreams: Chinese Films and National Subjectivity[J]. Hundred Schools in Arts, 2013(8):80.

[3] Wang Fei. Summary of the International Symposium of Screen World \& Chinese Dreams: Chinese Films and National Subjectivity[J]. Hundred Schools in Arts, 2013(8):80.

[4] Hou Guangming. Significance and Route of Construction of the Chinese Film School[N]. China Art. 2016-09-12.

[5] Zhou Xing. Construction of Chinese Film School: Concept and its Adaptability from the Perspective of Communications[J]. Modern Communication (Journal of Communication University of China), 2017(11):73. 